\title{
A QUANTITATIVE MODEL PROPOSAL FOR THE ASSESMENT OF PROJECT PERFORMANCE: THE BRIDGE MODEL
}

\author{
Zafer ALTIN 1 \\ Ömer LIVVARÇiN ${ }^{2}$
}

\begin{abstract}
Project performance models should serve as managerial measurement tools that evaluate the various aspects of projects with a holistic approach. However, predate models in the literature generally focus on limited performance indicators of projects - such as budget and time - for performance assessment and they lack broad perspective. In this respect, we aimed to introduce and propose a new model for the quantitative, effective and holistic evaluation of projects. The proposed model is originally developed as a conceptual approach by Livvarcin (2013) and entitled as The Bridge Model. In this study we enlarged the study and embodied the project performance parameters.

In this study, we examine project performance by focusing on two different parameter groups: Process parameters and indicator parameters. Process parameters include seven elements of The Bridge Model, these are preparation phase, initiation phase, implementation phase, closing phase, post-project phase, project atmosphere and project actors. Indicator parameters are measures that are similar to the project parameters used in existing project performance models and they include cost, time, quality, performance of outcomes, motivation, development and competitiveness.

We also performed a pilot study to figure out the performance of 42 different projects by using the performance parameters of the proposed model. We proved the validity and reliability of our model by using both quantitaive and qualitative methodologies.
\end{abstract}

Keywords: Project management, Project performance model, The Bridge model, Process parameters, Indicator parameters.

\footnotetext{
1Kara Harp Okulu, Savunma Bilimleri Enstitüsü, Teknoloji Yönetimi Bölümü, victorygold@gmail.com.

${ }^{2}$ Dr., Kara Harp Okulu, Savunma Bilimleri Enstitüsü, Teknoloji Yönetimi Bölümü, livvarcin@gmail.com.
} 


\title{
PROJE PERFORMANSI DEĞERLENDİRME MODEL ÖNERİSi: KÖPRÜ MODELİ
}

\begin{abstract}
ÖZ
Proje performans modelleri, bütüncül bir yaklaşım ile projelerin değişik yönlerini değerlendiren yönetimsel ölçüm araçlarıdır. Yapılan çalışmalar neticesinde, literatürde yer alan proje performans modelleri ve performans ölçüm kriterleri incelenmiş ve bu doğrultuda literatürde proje performansı ölçümü ile ilgili hususlarda eksiklik olduğu ve sadece bütçe, zaman gibi parametrelere odaklandiğı görülmüştür. Görülen bu eksiklikler üzerine, icra edilen projelere uygun etkin, bütüncül ve niceliksel proje performans modeli ve performans ölçüm kriterleri geliştirilmesi amaçlanmıştır. Bu model kavramsal olarak Livvarcin (2013) tarafindan ortaya konmuş ve köprü modeli olarak adlandırılmıştır. Bu çalışma ile önceki proje performans değerlendirme çalışmaları genişletilmiş ve proje performans parametreleri dahil edilmiştir.

Bu çalışmada, bir projenin performansı, yapısal ve parametrik ölçütler olmak üzere iki yönden incelenmektedir. Yapısal ölçütler projenin safhalarının değerlendirilmesine imkan sağlamaktadır. Performans ölçüm kriterlerinden yapısal performans ölçütleri köprü metaforu kullanılarak betimlenmektedir. Yapısal ölçütler, aynı zamanda köprü modelinin unsurları da olan hazırlık, başlangıç, gerçekleştirme, bitiş, idame süreci, atmosfer ve aktörler şeklindedir. Projenin parametrelerinin ölçülmesine imkan veren parametrik ölçütler ise literatürde var olan ve projenin performans parametreleri olan performans ölçütlerini oluşturmaktadır. Parametrik ölçütler, maliyet, zaman, kalite, çıktıları performansı, motivasyon, gelişim ve rekabet gücü olmak üzere 7 parametreden oluşmaktadır.

Bu çalışmada, önerilen modelin performans ölçütleri kullanılarak 42 değişik projenin performansı değerlendirilmiștir. Modelimizin güvenilirlik ve geçerliliğini ölçmek için niceliksel ve niteliksel olmak üzere her iki yöntemde kullanılmıștır.
\end{abstract}

Anahtar Kelimeler: Proje Yönetimi, Proje Performans Modeli, Yapısal ölçütler, Parametrik Ölçütler, Köprü Modeli.

\section{Introduction}

Project management includes complex and new activities (Schwalbe, 2007), and it has been recognised over the last 30 years that project management is an efficient tool to handle this complex activities (Munns and Bjermi, 1996). Project management provides adopting a management to quality production or supply process and coordinating of management's targets, steps and responsibilities. In this regard, project management is very important because it serves as a guide for the project team and practices of project management can help organisations to make a better plan, a better organisation, and a better management and work control which lead to better performance and increase productivity (Abbasi and Al-Mharmah,

2 | Celal Bayar Üniversitesi Sosyal Bilimler Dergisi - Cilt: 13, Sayı: 2, Haziran 2015 
2000; Loo, 2002). If projects have not appropriate project directory, they do not meet with the targeted results.

Nowadays, project management has become a key activity in most modern organisations (Belout and Gauvreau, 2004). Management realises that their organisations must implement project management practices to remain as a competitor (McHugh and Hogan, 2010) and much more organisations have to develop and execute innovative business strategies and projects in order to stay competitive (Srivannaboon and Milosevic, 2006). So, effective project management has been recognised as a necessity (McHugh and Hogan, 2010).

According to multiple empirical studies, a company's effectiveness partly depends on the success of its projects (Milosevic and Patanakul, 2004). These projects usually have a wide variety of objectives, involve numerous internal and external actors, and they are conducted in various activity sectors (Belout and Gauvreau, 2004). Wide objectives, expensiveness, long-term usage and high reliability of these complex projects are necessary in effective project management. So, because of many reasons, organizations need project management. A significant portion of financial resources and labor force are often allocated to the project management. To avoid the waste of these scarce resourses is the responsibility of the management (Qureshi at al., 2007). So it needs to boost up the performance. Performance is intangible, especially in case of management performance, so choosing tools for assessing the performance is also a hard job (Qureshi at al., 2007). In this context, the use of our project management model will provide much more efficient use of referred resources and it will serve to increase the performance of project.

Project management models in the literature, and performance measurement criteria were examined for this research. In this regard, it was seen that there was a lack in the issues in the literature that were related to project performance. As a result of these deficiencies, it was aimed to develop performance measurement criteria and an efficient project management model that was suitable for the project. We examine project performance with two aspects that are process criteria and indicator criteria. Process criteria allow the evaluation of the project's stages. We describe process performance criteria of performance measurement criteria by using the metaphor of the bridge. In this respect, our model is called the bridge model as a project management model. Process measures are also elements of the bridge model. This study focuses on whether bridge model that is the performance assessment 
model of project management makes a difference in the company performance or not and whether this model is enough for the assessment of project management performance or not.

\section{Literature review}

\section{A. The project}

In the literature, different project definitions that have the properties of a project have been made. In this context, according to the project management models of some countries and definitions of different sources, the common features of a project will be determined. Project means temporary activities which are carried out in order to produce the results, unique and distinctive products or processes (Pmbok, 2001). Unique means that the project is unprecedented. Even if projects occur in the same conditions, they are not the same and can not be operated any more. According to another definition, projects are the studies that show predetermined specific objectives in a timezone in order to achieve optimum use of resources (State Planning Organization, 1996). Timezone means that the project has start and due date. Due to a specific timezone, the start and due date of each project seem to be as it should be. A project is a temporary organization that is created for the purpose of delivering one or more business products according to an agreed business case (Prince2, 2009). From this description of the project, as a result of the project, it is necessary to occur a unique product, service or result. It shows that each project has an unequalled output. When the concept of the project is explained, it is remarked that it is "a one-off" and "unique", in Din 69901 (2009) German project management model that is different from others project can be explained as the works and tasks which have limits of time, target and resources and original organizational features. The salient subject in this defnition is that project has its own three constraints. These three elements are in question for each project. The purpose of all of the project is to reach the target by using the financial resources under the constraints of capital and time most efficiently.

According to us the projects are studies that are the unique and distinctive, occurred during in a certain period, have certain start and due date, can provide a product, service and they can be completed with written or oral agreements. This definition is adopted which is based on the model proposed in the third section.

\section{B. Project Management}

It is very important to manage a project. Definition related to the project that we have done, in line with the resources provided to achieve the desired goal, to be completed in the prescribed time, to meet the expectations of stakeholders are possible when the project

4 | Celal Bayar Üniversitesi Sosyal Bilimler Dergisi - Cilt: 13, Sayı: 2, Haziran 2015 
is managed. Thus, for a project, management becomes an important issue. Despite many publications on project management, it can not be placed on theoretical basis because it contains many disciplines (Smyth and Morris, 2007). Different project management definitions that have the properties of project management have been made. In this section, definitions of project management that are used by project management models of some countries and taken from different sources will be examined. On the basis of this definitions, properties of project management will be determined. Finally, definition of project management will be done by us for use in our model.

In a general definition, project management is all of the efforts expended at project management's processes that occurs throughout a project's life cycle. Here, the efforts that we call elements of this model, which start with the preparation phase that is the first phase and they finish with post-project process that is the last stage of our model. Knowledge, experience, skills, tools and techniques owned are the implementation of project activities in order to meet the needs of the project (Pmbok, 2001). With this definition, specific tools and techniques for the realization of the project implementation are highlighted. According to an other management model, project management is planning, delegating, monitoring and control of all aspects of the project, and the motivation of the staff involved in the project to achieve the project objectives within the expected performance targets for time, cost, quality, scope, benefits and risks (Prince2, 2009). With this definition, the motivation is very important to manage all components of the project and for the project team to achieve the desired goal. Ipma (2006) has given attention to the various elements of project management's concept. Another pm model, P2M (2005) has focused on the most appropriate technique and most effective work distribution tree when carrying out the project's products. Ipma (2006), especially has focused on the human element. When we examine, we see that the common aspects of project management models emphasize mostly are the implementation of the most efficient tools and techniques for the realization of the project, how all the components of a project that should be managed, human and in this respect the importance of the motivation.

When we examine definitions taken from different sources of project management, we see the general definitions. Project management is a set of principles, methods and techniques that people use effectively in planning and control of project work (Richman, 2002). According to another definition, project 
management is a management philosophy, a set of guiding principles and through management techniques to be able to meet up with the customer service demand and product demand (Berkley and Saylor, 1994). In these general definitions, project management is what sort of a management activity and its importance are emphasized and not only management of project's output, but also the demand for postproduction customer service are the components of project management that are emphasized.

In this respect, according to us, project management concept that can be used effectively is planning, performing, checking and sustaining of defined business or product with the optimal time, cost and motivation, with high development and competitiveness and with high quality. Also, knowledge, skills, tools and techniques are applied to the stage of our model to satisfy the needs. This definition means the basis of the model proposed in the third section.

\section{Parameters of Project}

While executing the project activities, without departing from the scope of the project, it is intended to complete in time with a predicted cost and defined resources. According to the study related to project management performed by Hughes and Williams (1991), to plan and manage a successful project, time, cost and scope of the three parameters are taken into consideration. However, even if these successful projects put a number of different needs forward, these projects are often constrained by these three parameters. Project has six parameters (Suvacl at al., 2013). These parameters are cost, time, scope, risk, quality, resources. For the execution of projects in a balanced manner, project constraints need to be run in a balanced manner in each project. In this respect, each constraint is interrelated. According to us, the parameters in accordance with the project that need to be regarded for the successful execution of projects are cost, time, quality, performance of outcomes, motivation, development, competitiveness. These parameters are described in detail in the third part of this study.

The parameters placed above also constitute the constraints of the project. All of these constraints are associated with each other. Any other changes in the constraints also affect other project parameters. For example, when it is necessary to increase the quality of a project, the project costs must be increased. Also in this case, time will also be arisen as another constraint. This increase in quality constraints will directly affect competitiveness and development parameters.

6 | Celal Bayar Üniversitesi Sosyal Bilimler Dergisi - Cilt: 13, Sayl: 2, Haziran 2015 


\section{Project Performance Models}

In the sections above, we have explained that each project has determined quality standards, project's constraints or parameters. Each activity that has an important place in the continuation and termination of project and the compliance of each activity with these constraints constitutes the performance evaluation of the project.

In the literature, various project performance criteria and methods are available. However, as pointed out by Turner[49], although many of the research in this particular area have adopted broader definitions of project success, the traditional triple constraint criteria seem to prevail. As a result of the compromise reached among researchers, project performance criteria focus on time, cost and quality objectives that are triple constraints of the traditional approach (Collins and Baccarini, 2004). In the narrow sense, project performance measures that focus on constraints are called the golden triangle or iron triangle (Bourne and at al., 2000). In a broader sense, except the traditional constraints, project performance factors include requirements for orientation of stakeholders in the managed project and especially include necessary considerations for development of customer orientation in the project management process (David and Gillian, 2007). In terms of triple constraints, product and process performance are two key dimensions of project performance. According to Wallace et al. (2004), while process performance that is terminated with project with required budget and time, product performance is a quality of system, service, product which are result of projects. It is important to study both aspects of project performance, because there is a potential conflict between the efficiency of the process and its quality (Jun at al., 2011). In the traditional sense, except the triple constraints which are used by project performance measurement, different project performance criteria are available. For example, project performance criteria are cost, structural speed, delivery speed, cost development, program development and quality in a project (Konchar and Sanvido, 1998). Chan and Chan (2000) examine the performance of the project with the six criteria. According to Chan and Chan (2000) these criteria are expectations and satisfaction of user, environmental performance, health, safety, commercial value. According to Sai at al., (2004), project performance measures are analyzed in eight categories. These are people, cost, time, quality, health, safety, customer satisfaction, environment and communication. 
When we examine the methods of project performance, we face with two methods. These are scorecard method of project performance and earned value analysis method.

-Scorecard method of Project performance; According to Barclay (2008), scorecard method of project performance evaluated project performance as a result of the six-dimensional framework. These six dimensions are project lifecycle vision, snow vision, innovation and learning vision, quality vision, user and stakeholder vision. Project performance scorecard includes why projects which interact with key stakeholders and used in the performance evaluation of project outcomes are important. The project performance scorecard provides project performance measurement system for the evaluation of projects which include the opinions of different stakeholders throughout life cycle of projects. Thus, it attempts to integrate to issues in a wide range.

-Earned value analysis method; for measuring the performance of the project, planned work is compared with actual work and the most common method is used to measure performance of ongoing projects (Anbari, 2003). Earned value analysis method is an important guideline for the control systems of a company management. For a manager in the company it is important to know that how much time and cost will be necessary to complete the project, and also it is one of the responsibilities of the manager. Earned value analysis method makes control whether there has been development in the early stages of the project in accordance with the budget and time and by doing this the fulfillment of this responsibility is ensured. According to Sharma (2013), earned value analysis shows project plan and value of completion works. Earned value analysis includes how much time and cost are spent for the project until now and includes how much time and cost will be needed in the future.

We examine project's performance with two aspects. These aspects are process criteria and indicator criteria. Process criteria and indicator criteria are for the evaluation of project performance.

\section{Methodology}

In this study, as a starting point, models of project management and performance measurement criteria in the literature are examined. In this respect, the lack of related matters about project management performance have been identified. As a result of these deficiencies, it is aimed to develop an effective project management model and a performance measurement model in accordance with executed project. In this study, it is benefited from members of the Turkish Armed Forces personnel that are 
responsible for project management and is benefited from personnel who have served in important project of defence industry in Ankara. For this purpose, first the performance parameters and performance measurement model have been revealed in the literature then it has been revealed performance criteria which should be in a project. Population of study consists of members of the Turkish Armed Forces personnel that are responsible for project management and it consists of public institutions involved in the defence sector. For the study 31 participants from 4 different organizations are selected and asked to assess their projects. Participants filled out 42 surveys since some of the participants were involved in two or more projects. Each survey represents one project. As a result of the appointment, experts in management positions informed people about the purpose of the study and the content of the interview, this interview lasted for 15-20 minutes. In order to motivate participants, router dialogue has been established. The questionnaire developed for this study is composed of two sections and 14 questions. The questionnaire is prepared by using a 9-point Likert-type scale. It is aimed to be able to measure project performance effectively with prepared questions. Reliability and validity tests are reviewed including qualitative and quantitative way. To measure the reliability of the study, Cronbach's Alpha and factor analysis methods are used. Cronbach's alpha and factor analysis are performed on two sets of data. In addition, works of the staff are tested by making observation in the work field whether the responses take place in work-site or not and the responses are reliable or not. Research for the validity of expert opinions are used. Interviews with experts who have taken part in projects, support the validation of the survey.

\section{Proposed Model}

We examine project performance with two aspects. These aspects are processes parameters and indicator parameters. Process criteria allow the evaluation stage of the project. Process measures are also elements of the bridge model. These elements are seven pieces including preparation process, initiation process, implementation process, closing process, post-project process, the atmosphere and the actors. Indicator measures are measures of the project parameters. These measures consist of the parameters existing in the literature. Indicator measures are seven pieces including cost, time, quality, performance of outcomes, motivation, development and competitiveness. Firstly, we will examine process parameters which are described as bridge model. 


\section{A. Process parameters}

Process performance criteria of performance measurement criteria are described by using the metaphor of the bridge. In this respect, our model is called the bridge model as project management model. We have created a conceptual model of project management that consists of seven elements. These elements are shown in Figure 1. Process measures are also elements of the bridge model.

We emphasize that the bridge model consists of seven elements. These elements are a collection of logically associated activities. Generally, These elements are completed and finalized with important output. Project phases constituting the bridge model are explained as follows.

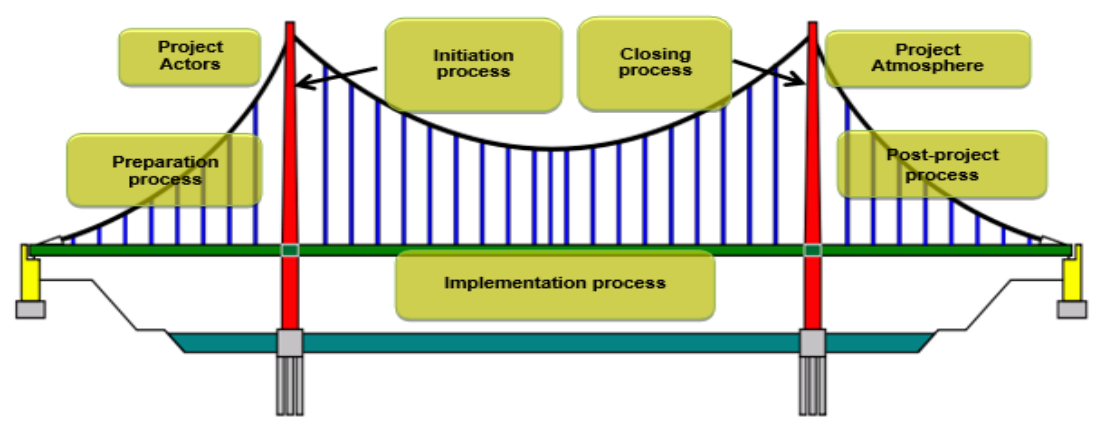

Figure 1: Bridge Model

We emphasize that the bridge model consists of seven elements. These elements are a collection of logically associated activities. Generally, These elements are completed and finalized with important output. Project phases constituting the bridge model are explained as follows.

\section{A.1 Project preparation phase}

Preparation phase is the first phase of bridge model. This phase represents the entry stage which leads to the project initiation phase. At this phase, ideas for project are assessed and prepared. The goal of the phase is to ensure whether some preliminary conditions for the initiation of the project are met or not, and to review project's feasibility. Project preperation phase is a phase that is deviced for preventing badly designed and badly beginned projects. At this phase, while deciding whether the project is worth to start or not, discharging the minimum responsibilities are one of the important elements. 


\section{A.2 Project initiation phase}

Project initiation phase for the purpose of implementation of project on strong fundamentals, aims to describe the project in a more detailed manner than its developed condition. At currently applied projects, we see that the initiation phase is not taken into account in details. At the initiation phase which represents the first step of our bridge model, the importance of contract and project plan are emphasized in detail as they are the key criterion for project's success.

The aim of this phase is to provide a more clear and wider approach to those aspects which will either be faced at supply and production stages, or be faced at the completion of the project. In this respect, various documents that describe various facts of the project should be gathered, elements which may effect the general performance of the project should be taken into account, and the importance of the contract and the plan of the project should be emphasized. Furthermore, all information obtained and recorded at the initiation phase, outcomes of project, and the method that is considered to be used, will constitute a base of general aproach to project parties. At the end of the initiation phase, an agreement should be obtained betwen parties. If before a reconciliation is obtained between the parties, it is passed to the execution phase, irrevocable damages might be encountered. The most important element of this phase is agreement. To be able to commence and continue the project in a right manner, it is of paramount importance to have a clear, identically understood, and measurable agreement. When it is decided to continue to the project, the project initiation phase is stepped in. At the project initiation phase, a detailed plan is drawn, and project management strategy and control are defined. Project description document and project contract that contain project plan are produced.

\section{A.3 Project implementation phase}

Implementation phase is about consolidating and making of project activities into project plan in conformity with project contract. It is the phase in which the project is commenced to execute and in which these execution activities are managed. At our model, implementation phase consists of having project outputs via manufacturing, supplying, monitoring and reviewing of these activities. Implementation of the project which represents the road betwen bridge's models, is an important success criterion that assess project's outputs. Most of project sources, general period and total budget are consumed in implementation phase. Project's effectiveness and durability are determined at this phase. This phase 
is managed within our model's restrictions such as time, cost, quality, competitiveness, motivation, development and output performance. Problems and risks are taken into account, and relevant products produced and supplies are made.

\section{A.4 Project actors}

Definition of actors is a period where all perons and institutions that affect and are effected by the Project are defined, and in accordance with their requests, information about their effects on the project's success are documented. If it is thought that each actor's expectations from and their contributions into the project and their view angle about the project may differ one from the other, it is seen that it is important to turn actors' requests into a managable project goal. Besides, for the sake of preventing conflicts which may be encountered in the future, it is important to draft Project actors' shared goals and expactations into a written agreement. Distribution of roles between project actors is important throughout the lifetime of the project. Distribution of roles should be made correctly and duties should be defined clearly. In this course, it could be clearly monitored whether actors do their share of roles or not. Our model considers Project actors criterion such as defining of project actors, defining of roles clearly, conformity of sharing of roles as an important success and performance criterion. Actors consist of clients, sponsors(contractors), project team and project manager.

\section{A.5. Project Closing Phase}

The implementation purpose of this phase is to ensure that the testing and assessment are done, all of the delivery of the project are made and there are not any transaction matters that are left unclosed. In this process, the procedure for completion of the project is fulfilled and it is being announced officially to all sides of the project. For a qualified closing process of the project, there is a need to have a good documented scheduling and tracking stages. The informations that are recorded in previous phases of the project will help to complete it in a healthy way. If the completion of the previous phases is not successful, the probability of finishing the project will be weak. Such as the previous stages of the lifecycle of project, the completion of it has to be managed well. This is not a sign that the project is completed what if only product, service or output of project have been served in project completion process. The result of the project must meet the expectations of all participants when the project is finished. The important function of project completion process is that to take an officially acceptance form that is signed by all actors as regards the project output is accepted by them and put in a file with project documents to provide the project output and it is

12 | Celal Bayar Üniversitesi Sosyal Bilimler Dergisi - Cilt: 13, Sayı: 2, Haziran 2015 
officially accepted by participants and the main goal of the project completion phase is emphasized.

\section{A.6. Project Post-project Phase}

After the completion of project closing process, the sequel of project activities is implemented as a last stage of project lifecycle. This is the process that starts after product manufacturing process finishes and it is given to the customer or user. Also the post-project process provides activity and responsibility to reach to the sustainability targets and continuously monitoring throughout the product's lifetime. A successfull project management cycle is proportional to "Continuous Improvement" (Kerzner, 2005). According to the researchs, it has been realized that customer satisfaction has increased at the end of the continuous improvement. Continuous improvement is a part of the sequel of project process, it includes the information about usage - which is about project output - that are gotten from customer after it has been used by them. With the evaluation of this information, continuous development of the project outputs are provided. This information is the basis for activities in the post-project process.

\section{A.7. Project Atmosphere}

Due to the nature of the project during the realization of a project, many parties will be affected by project's activities and results. These parties which are one of the pillars of our project management model are actors in the project. All the actors' satisfaction is very important during the project realization. The atmosphere of the project includes how much support actors contribute to the project, actors' expectations from the project, communication skills among actors, project implementation environment and satisfaction of the actors about the project. Satisfaction of the expectations of people, customers and sponsors and a desire to make new investments indicate that the projects atmosphere is positive.

\section{B. Indicator parametric criteria}

In the first chapter we have examined the process parameter which is the first part of our model. In the second part we will examine the indicator parametric criteria which are second part of our model. Indicator measures are measures of the project parameters. These measures consist of the parameters existing in the literature. Indicator measures are seven pieces including cost, time, quality, performance of outcomes, motivation, development and competitiveness. 


\section{B.1 Cost}

The Project cost is the sum of expenditures that are required for the life cycle stages of our model such as preparation process, initiation process, implementation process, closing process and postproject process steps that our model have. Cost includes people who work on the project, use supplies, equipment, money or all events and items that require fort he attention of anyone. The cost criteria, one of the parametric performance criteria, measures that whether the project remains in the aimed cost or not.

\section{B.2 Time}

Time parameter includes the following time processes; these are allocation of resources to activities, monitoring and control application time, work packages and programming of activities, the preparation process, realization process, closing process and postprocess projects. The time criteria, one of the parametric performance criteria, measures that whether the project remains in the aimed time or not. Time parameter denotes the end time of a project and it states that how much time it takes to carry out the project activities. How much time is necessary for the followed planning and what kind of activities and measures should be taken against disruptions are realized by means of time control.

\section{B.3 Quality}

Project outputs must fulfill certain quality requirements. These requirements are also applied to intermediate products. In particular, in the first phase of the life cycle of our model, it is important to determinate, to be agreed on and to record the quality requirements. Requirement list should be checked again at the end of implementation stage. This check provides that if output characteristics of the project is appropriate to desired feature or not. Quality criteria measure the quality of all requirements throughout the project and project outcomes.

\section{B.4 Output Performance}

Output Performance criterion, also one of the parametric performance criteria, is a measure of to what extent and in what qualities achievement of the objectives of the project or output of project. Output Performance criterion assess whether the performance of the project output is sufficient. Defined quality standards are available for each Project. The compliance of each project with defined quality standards of time, cost and scope constraints which are the overall project constraints is the evaluation of project performance. 


\section{B.5 Motivation}

Motivation parameter is to energy for achieving the high objectives and to overcome obstacles to change. The motivation criteria, one of the parametric performance criteria, measures that if the motivation is enough throughout the project or not. Due to the nature of the project, many sides will be affected by project's activities and results during the realization of the project. These sides are users, contractors, project teams, sponsors, businesses. Satisfaction and motivation are very important during the project realization of all actors. Motivation parameter consists of how much support the actors contribute to the project, expectations of actors from the project, satisfaction of actors from the project, contribution to the project's motivation of actors. Fulfilling the expectations of actors and requests to make new investments show that actors have positive motivation.

\section{B.6 Development}

Development is the systematic use of scientific and technical knowledge to meet specific objectives or requirements or an extension of the theoretical or practical aspects of a concept, design, discovery, or invention. On the other side, development of technology is to gain mastery of information for the creation of a product or as a result of applied research, it is activity applied to a new product of obtained results. Development is one of the parametric criteria that assesses how project outcomes contribute to the technological development. Not only Projects do not contribute to technological development with the resulting output but also the information obtained during the project's implementation may affect the current technological development. Development parameter measures whether producing knowledge in order to understand a particular subject contributes to development of systems using with obtained technology or not.

\section{B.7 Competitiveness}

With the realization of the project, in-house innovation and $R \& D$, new product development efforts are increasing. Projects increase profitability and competitiveness of business. For example, the country's defense industry companies have made the tank project that adds competitiveness to these companies in the international arena. Competitiveness which is one of parametric performance criteria to evaluate project is to contribute to the competitiveness of contractors. Each project is an important contribution to the project actors. While projects offer users the opportunity to benefit from the project results, also they can contribute to the development, growth, prestige and competitiveness to businesses. Companies can not profit 
from each project but can continue growth and development due to adds to the prestige of project. This development provides adaptability to the environment to business and it can be put up against the pressures of the environment for business. Businesses developped by successful projects can provide to offer qualified services to the customers while they are fighting with their competitors easily.

\section{Pilot Study}

The purpose of this section is to introduce the empirical pilot study of the proposed model. For the pilot study 31 participants from 4 different organizations are selected to be interviewed about their projects. Participants filled out 42 surveys since some of the participants were involved in two or more projects. Each survey represents one project.

In this pilot study, performance of 42 projects were measured. The overall performance of the project is obtained through two steps. First process criteria are measured after then indicator criteria are measured. Questionnaire is composed of 2 sections and 14 questions. The first section includes 7 questions which measure process performance of the project. Similarly, the second section includes 7 questions which measure indicator criteria of the project. Each section is developed as a separate sheet in the same MS Excel file and participants are asked to fill in all sections. The routing instructions for each section are provided on the top of the sheet which includes related questions.

As explained before, the overall performance of the project is obtained through two steps. First step is process criteria. Process criteria measure performance of project's phases. In the first part it researches answers to the question "how much success was obtained from process criteria?". The second step is indicator criteria. Indicator criteria measure performance of project's parameters. In the second part it researches answers to the question "how much success was obtained from indicator criteria?". The summation of process measurement criteria and indicator measurement criteria will give total project performance value.

This pilot study might be accepted as a kind of feasibility study which is a small scale version, or trial run, done in preparation for the major study (Polit, Back and Hungler, 2001: 467)". The pilot study is performed on 31 participants from 4 different organizations and Participants fill out 42 survey. Participants expressed that the questionnaire was easy to understand. Common belief was that the margins of answers were demonstrated clearly and there was no confusion in answering the questions. The questionnaire was applied

16 | Celal Bayar Üniversitesi Sosyal Bilimler Dergisi - Cilt: 13, Sayı: 2, Haziran 2015 
two times, with 2-3 week time difference, for reliability and validity analysis. Survey results are as shown below:

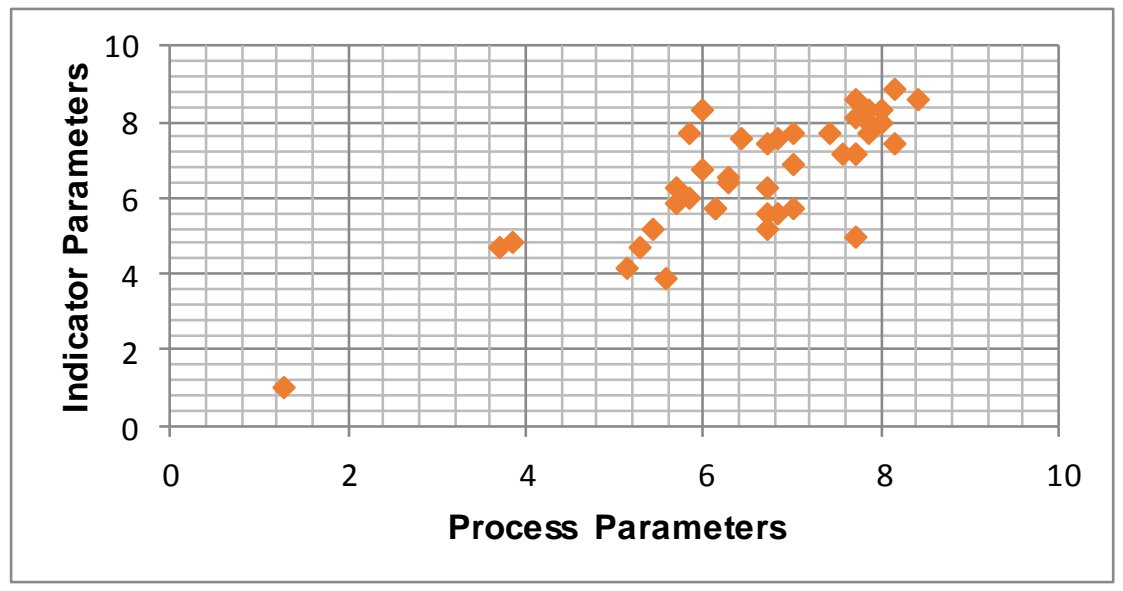

Figure 2: Measurement of Parameters

Every point in the graph above indicates a project and its performance where horizontal and vertical axes represent the average of process parameters and indicator paramters respectively. When results assessed it is seen that most of the projects are succesfull both process wise and indicator wise.

So far the overal performances of the projects are evaluated. In the following sections the process and indicator parameters will be assessed seprarately.

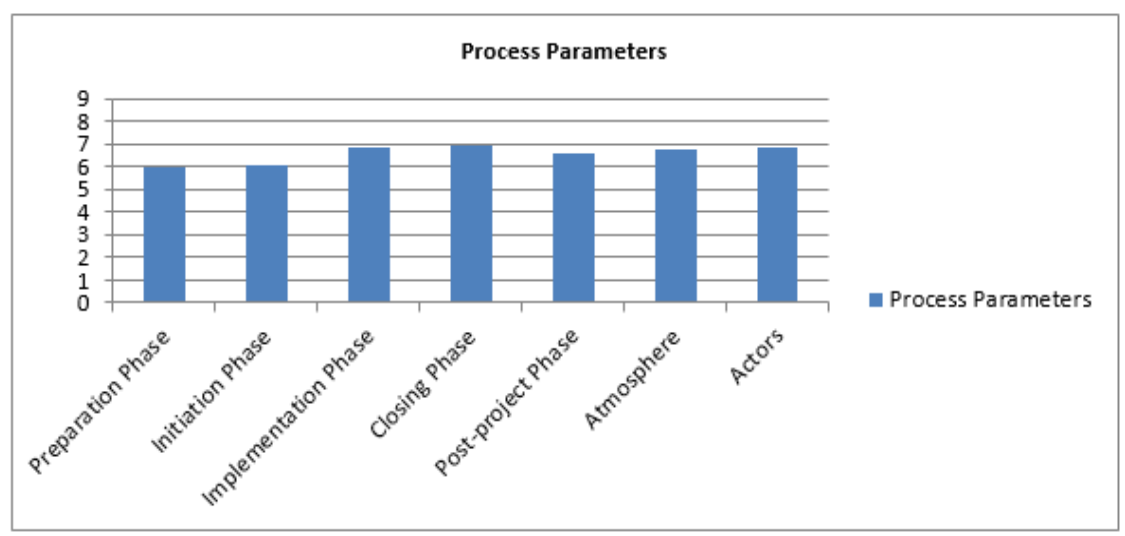

Figure 3: Averages of Process performance metrics 
It is observed that the process parameters measure project phases with success as a result of interviews and surveys. Preparation phase is the first phase of the project. Preparation phase represents feasibility stage of project. Preparation phase is the stage where ideas are explored and prepared for project. The assessment of the preparation phase is seen to be generally positive and it is seen that projects begin through appropriate preparatory phase. Initiation phase is the second phase of the project. When the responses related to the management of the initial phase are examined, it is seen that projects contract are appropriately prepared before conducting and project plans are prepared for project management effectively. Implementation phase is the third phase of the project. Considering the stage of project implementation, whether supply or production, along with coordination of people and resources, it is seen that project activities are managed in accordance with the project plan and project contracts. Closing phase is the fourth phase of the project. In the last stage of the project, it is seen that testing is done effectively, project experiences are shared and products are delivered seamlessly to the customer. Post-project phase is the fifth phase of the project. It is seen that warranty, maintenance and logistics support activities of post-project activities are emphasized and it is observed that management of post-project phase is successful. Actors are the sixth element of project. It is seen that project actors are determined with success and it is observed that missions and roles are distributed with success. Atmosphere is the seventh element of project. Analyzing the project management of the atmosphere, the satisfaction of the actors involved throughout the entire project is successfully achieved and it is seen that communication between them is realized effectively.

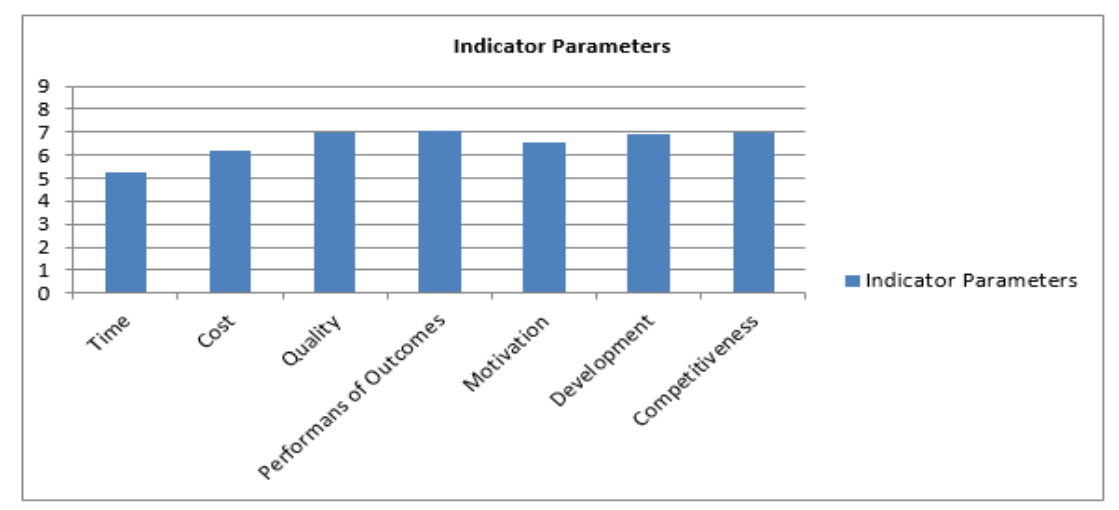

Figure 4: Averages of Indicator performance metrics

18 | Celal Bayar Üniversitesi Sosyal Bilimler Dergisi - Cilt: 13, Sayı: 2, Haziran 2015 
Similarly, it is observed that the indicator parameters measure project parameters with successful as a result of interviews and surveys. It is seen that realized projects remained within the aimed cost and it is seen that project takes place as soon as possible for its intended time. The average answer for "time" is 5.23 which means average performance in terms of schedule. On the other hand, we have better results for "budget" where the average is 6.16. It prooves that the assessed projects are generally finished in the expected budget limitations. When carrying out the project, it is seen that attention is paid to the quality criteria at each stage. It is seen that performance of project outcomes is suited for intended quality standards and seen that system, whether manufactured or supplied, fulfill the given task effectively to itself. it is seen that motivation of all actors along the stages of the project have been fulfilled and expectations are met. The information and results obtained from the project will contribute to technological development as a result of the project and they load and allow the increase of the competitiveness of the project contractors.

\section{A. Reliability and Validity Analysis}

Reliability and validity tests are performed on the data collected for the pilot study. Sample size is 42 . The quality of a qualitative research is dependent to the concept of truth and the question of whether truth is universal or local and determinable (Moret et al., 2007). According to many authors (Glesne and Peshkin, 1992, p. 8; Patton, 2002), criteria used for quantitative research are also applicable in qualitative research, which are to say that validity and reliability are meaningful concepts in qualitative research as well.

Qualitative research and quantitative research do not exclude each other. It is more useful to view both different and related approaches that may be involved in practice by using several different methods for data collection and analyses, some qualitative, some quantitative.

Although reliability and validity are treated separately in quantitative studies, Golafshani (2003) claims that these terms are not viewed separately in qualitative research. Instead, terminology that encompasses both credibility, transferability, and trustworthiness is used (Golafshani, 2003). In this study the term "reliability and validity analysis" is used both for quantitative and qualitative analysis but the differences related to the particular procedures and tests are considered. Quantitative and qualitative reliability and validity analysis are explained separately in the following sections. 
As stated above, the questionnaire developed for this study is composed of two sections and 14 questions. First section is process criteria. Second section is indicator criteria. All quantitative reliability and validity tests are performed on all sections separately and twice.

\section{A.1 Quantitative Reliability and Validity Analysis}

First test is the internal consistency which is basically estimation based on the correlation among the variables compromising the set and is expressed with Cronbach's alpha values which are based on average correlation among items. In our study, the alpha coefficients are all over 0.80 and therefore acceptable (Table 1). Cronbach's alpha values for two data sets are provided below:

Table 1: Internal Consistency of sections

\begin{tabular}{|c|c|c|}
\hline Section & $\begin{array}{c}\text { Cronbach's } \\
\text { Alpha }\end{array}$ & $\begin{array}{c}\text { Cronbach's Alpha } \\
\text { Based on } \\
\text { Standardized Items }\end{array}$ \\
\hline Process criteria (Data Set 1) & 0,911 & 0,911 \\
\hline Indicator criteria (Data Set 2) & 0,839 & 0,839 \\
\hline
\end{tabular}

Second test is the explarotary factor analysis of all two sections for two data sets and in this study, Principal Component Analysis is performed. The results are analyzed in this section. Analysis of the results is as shown in the following table. The only factor is reached that associated with process measurement criteria as shown in Table 2. These results indicate that issue of seven criteria have a common sense and can measure the success of the management of the phases of the project. Seven of criteria represent one dimension and demonstrates that can measure performance of project's processive. When table 3 is examined, it is observed that 2 factors is reached associated with indicator measurement criteria. While Cost and time factor represent one factor, the other five parameters represent a different factor. While Budget and time is measuring one dimensional in the same subject, other parameters measure different dimensional in the same subject. 
Table 2: Rotated Component Matrix of process criteria ComponentData Set 1

Component Matrix ${ }^{a}$

\begin{tabular}{|c|c|}
\hline & Component \\
\hline & 1 \\
\hline Preparation phase & ,771 \\
\hline İnitiation phase & ,819 \\
\hline $\begin{array}{l}\text { İmplementation } \\
\text { phase }\end{array}$ & ,816 \\
\hline Closing phase & ,844 \\
\hline $\begin{array}{l}\text { Post-project } \\
\text { phase }\end{array}$ & ,709 \\
\hline actors & ,870 \\
\hline atmosphere & ,837 \\
\hline
\end{tabular}

a. 1 components extracted.

Table 3: Rotated Component Matrix of indicator criteria Component Data Set 2

\begin{tabular}{|l|l|l|}
\hline \multicolumn{3}{|c|}{ Rotated Component Matrix ${ }^{\mathbf{a}}$} \\
\hline \multicolumn{3}{|l|}{ Component } \\
\cline { 2 - 3 } & 1 & 2 \\
\hline Cost & 164 &, 874 \\
Time &, 183 &, 849 \\
Quality &, 728 &, 473 \\
Performans of outcomes &, 783 &, 341 \\
Motivation &, 740 &, 190 \\
Development &, 805 &, 093 \\
Competitiveness &, 840 &, 079 \\
\hline
\end{tabular}

Extraction Method: Principal Component Analysis.

Rotation Method: Varimax with Kaiser Normalization.

a. Rotation converged in 3 iterations. 


\section{A.2 Qualitative Reliability and Validity Analysis}

Reliability and validity in qualitative research are also known as "credibility" and "trustworthiness" (Olshansky, 2005). Credibility refers to "ensuring that the theoretical framework generated is understood and is based on the data from the study (Olshansky, 1995)" and trustworthiness refers to "extent to which one can believe in the research findings" (Glaser and Strauss, 1967 as cited in Olshansky, 2005).

Firstly our strategy spends significant time just for developing a trusting relationship with research participants, observing and interacting in various contexts over time. Secondly our strategy includes multiple methods of data collection, multiple investigators, and multiple contexts/situations. We have performed a lot of informal interviews with participants and established comprehensive analysis of existing approaches in the literature. This study was conducted of 31 participants and the questionnaire was applied twice to measure test-retest reliability and triangulation.

\section{Concluding Discussion}

According to the results of this study, it is seen that total performance of the project is successful and it is observed that performance of the project can be measured by our proposed "Bridge Model". Although this research application indicates results only for a limited pilot study we can derive significant output both in terms of literature and real business life. For example, in this stusy it is seen that performance of 7 project is managed at moderate success and performance of 1 project is managed with failure.

This study might have significant contributions to the business (especially to the top managers and project makers of organizations) because it proposes a set of tools for project performance evaluation, and for the diagnosis of project problems. This study aims to provide necessary information for managers about project performance measurement to do their tasks successfully. This study provides contributions to the management literature because it proposes a new, empirical and holistic approach for understanding project management and also establishes a measurement tool for the evaluation of project performance.

The conceptual framework of project performance model provides a generic expression and may also be useful in different projects. Project performance model can be improved by adding different parameters and Project performance model can be improved by giving coefficient to parameters. Model applied to projects in different areas can increase the accuracy and reliability of the model.

22 | Celal Bayar Üniversitesi Sosyal Bilimler Dergisi - Cilt: 13, Sayı: 2, Haziran 2015 


\section{REFERENCES}

ABBASI, G.Y., AL-MHARMAH, H., 2000, " Project management practice by the public sector in a developing country", International Journal of Project Management, Volume 18 /2, ss.105-109.

ANBARI, F.T., 2003," Earned Value Project Management Method and Extension", Project Management Journal, Volume 34 /4.

BARCLAY, C., 2008, "Towards an integrated measurement of IS project performance: The project performance scorecard." Springer Science, ss. 331-345.

BELOUT, A. and GAUVREAU, C., 2004, "Factors influencing project success: the impact of human resource management", International Journal of Project Management, Volume 22, ss. 1-11.

BERKLEY, B. T. and SAYLOR, J. H., 1994, "Customer-Driver Project Management", New York: McGraw-Hill.

BOURNE, M., Mills, J., WILCOX, M., NELLY, A., and PLATTS, K., 2000, "Designing, implementing and updating performance measurement systems", International Journal of Operations \& Production Management. Volume 20/7, ss.754-771.

CHAN, E. H. W. and CHAN, A. T. S., 2000, "Imposing the ISO 9000 quality assurance system on statutory agents in Hong Kong", J. Constr. Eng. Manage, Volume 125/4, ss. 285-91.

COLLINS, A. and BACCARINI, D., 2004, "Project success - A survey. Journal of Construction Research", Volume 5/2, ss. 211-231.

DAVID, J. B. and Gillian, H. W., 2007, "Project Management Priorities and the Link With Performance Management Systems", Project Management Journal, ss 5-11.

State Planning Organization (Devlet Planlama Teşkilatı), 1996, "Investment and Project Description (Yatırım ve Proje Tanımı)", Ankara, State Planning Organization.

DIN 69900, 2009. Project Management. Network Analysis.

GLESNE, C., and PESHKIN, P., 1992, "Becoming qualitative researches: An introduction", NY: Longman, New York.

GOLAFSHANI, N., 2003, "Understanding Reliability and Validity in Qualitative Research, The Qualitative Report", Published on world wide web: http://www.nova.edu/ssss/QR/QR84/golafshani.pdf, Volume 8 Number 4. 597-607

HUGHES, T. and WILLIAMS, T., 1991, "Quality Assurance", BSP Professional Books, Oxford.

IPMA., 2006," ICB - IPMA Competence Baseline, Version 3.0. The Netherlands: International Project Management Association"

INCELER, H., 1995," Economic and Social Implications of Technology Management (Teknoloji Yönetiminin Ekonomik ve Sosyal 
Etkileri)" Doctorate thesis. Social Sciences of Istanbul University Institute, Istanbul.

JUN, L., QIUZHEN, W. and Qingguo, M., 2011, " The effects of project uncertainty and risk management on IS development project performance: A vendor perspective", International Journal of Project Management, Volume 29, ss. 923-933.

KERZNER, H., 2005, " Strategic Planning for Project Management Using a Project management Maturity Model", 2nd Edition John Wiley \& Sons Company. Inc New York. s.19.

KONCHAR, M. and SANVIDO, V., 1998, "Comparison of US project delivery systems", J. Constr. Eng. Manage. Volume 124/6, ss.435-444.

LIVVARCIN, 0. 2014, "An Analytical Model Proposal for Project Management: The Bridge Model, Presented in Vector Study Group 90 Minutes Workshop 1 (VSG-90mW-1)", Ankara, Turkey, 21 April.

L00, R., 2002, "Working towards best practices in projectmanagement: a Canadian study", International Journal of Project Management. Volume 20 /2, ss. 93-98.

MCHUGH, O. and HOGAN, M., 2010, "Investigating the rationale for adopting an internationally-recognised project management methodology in Ireland: The view of the project manager", International Journal of Project Management, Volume 10.

MILOSEVIC, D and PATANAKUL, P., 2005,"Standardized project management may increase development projects success", International Journal of Project Management, Volume 23, ss.181-192.

MORET, M., REUZEL, R., VAN DER WILT, G.J., and GRIN, J., 2007. Validity and Reliability of Qualitative Data Analysis: Interobserver Agreement in Reconstructing Interpretative Frames, Field Methods, Published on the world wide web http://fmx.sagepub.com/cgi/reprint/19/1/24.

MUNNS, A.K. and BJERMI, B.F., 1996, " The role of project management in achieving project success", International Journal of Project Management, Volume 14/2, ss 81-87.

OLSHANSKY, E., 2005, "Reliability and Validity in Qualitative Research", Published at world wide web.http://cnr.nursing.pitt.edu/RMS\%20Presentations/Reliability\%20 and\%20Validity\%20i\%20Qualitative\%20Research.ppt, Presented at University of Pittsburg on October 17, 2005.

P2M., 2005, "A Guidebook for Project and Program Management for Enterprise Innovation", Project Management association of Japan (PMAJ). 
PATTON, M. Q., 2002, "Qualitative evaluation and research methods, 3rd edition ", Thousand Oaks, CA: Sage Publications, Inc.

POLIT, D.F., BECK, C.T. and HUNGLER, B.P., 2001,"Essentials of Nursing Research: Methods, Appraisal and Utilization, 5th Ed", Philadelphia: Lippincott Williams \& Wilkins.

Prince2., 2009, "Managing Successful Projects with Prince2tm. United Kingdom: The Office of Government Commerce."

Project Management Institute, 2001, " A Guide to the Project Management Body of Knowledge(Pmbok), forth ed", Project Management Institute, Newtown Square, PA.

QURESHI, T.M., WARRAICH, A.S. and HIJJAZI, S.T., 2008,"Significance of project management performance assessment (PMPA) model", International Journal of Project Management.

RICHMAN, L., 2002, "Project Management Step-by-step" : AMACOM, New York.

SAI, O.C., HENRY, C.H.S and KEVIN, K.W.C., 2004, "PPMS: a Web-based construction Project Performance Monitoring System", Automation in Construction. Volume 13, ss. 361-376.

SCHWALBE, K., 2007, "Information Technology Project Management Course Technology", Thomson Learning . Boston, MA.

SHARMA, V.K., 2013, "Earned Value Management: A Tool for Project Performance", Advances In Management. Volume 6, ss.37-42.

SMYTH, H.J. and MORRIS, P.W.G., 2007,"An epistemological evaluation of research into projects and their management: Methodological issues", International Journal of Project Management. Volume 25/4, ss. 423-436.

SRIVANNABOON, S., MILOSEVIC, D.Z., 2006, "A two-way influence between business strategy and project management", International Journal of Project Management. Volume 24/6, ss. 493505.

SUVACI, E., LEZKI, S., UYSAL, O., ONCE, S., Er, F. and SIKLAR, E., 2013, " Project Management (Proje Yönetimi)", Anadolu University Press (Anadolu Üniversitesi Yayını), Eskisehir.

TURNER JR.,1999," Editorial: Project management: a profession based on knowledge or faith", International Journal of Project Management, Volume 17/6, ss. 329-30.

WALLACE, L., KEIL, M. and RAI, A., 2004, "How software project risk affects Project performance: an investigation of the dimensions of risk and exploratory model", Decision Sciences. Volume 35 (2), ss. 289-321. 
